The University of Maine

\title{
DigitalCommons@UMaine
}

Marine Sciences Faculty Scholarship

School of Marine Sciences

$2-1-2001$

\section{Humesiana, a Remarkable New Cumacean Genus from the Caribbean Sea}

Les Watling

University of Maine - Main, watling@maine.edu

S. Gerken

Follow this and additional works at: https://digitalcommons.library.umaine.edu/sms_facpub

\section{Repository Citation}

Watling, Les and Gerken, S., "Humesiana, a Remarkable New Cumacean Genus from the Caribbean Sea" (2001). Marine Sciences Faculty Scholarship. 56.

https://digitalcommons.library.umaine.edu/sms_facpub/56 


\title{
HUMESIANA, A REMARKABLE NEW CUMACEAN GENUS FROM THE CARIBBEAN SEA
}

\author{
Les Watling and Sarah Gerken \\ Darling Marine Center, University of Maine, Walpole, Maine 04573, U.S.A. \\ (LW e-mail: watling@maine.edu)
}

\begin{abstract}
A B S T R A C T
Most nannastacid cumaceans collected from tropical waters belong to just a few genera, among them the nearly ubiquitous genus Cumella. A new nannastacid genus is described from the West Indian island of Guadeloupe. Members of the genus possess a very long and robust pleonite 6 and short and stubby uropods and share the loss of the ischium on pereiopod 2 and maxilliped 2 . This new genus is clearly allied to three species within the genus Cumella, all of which have elongate pleonite 6 and short, but not robust, uropods. These three species are known from the Caribbean Sea, Red Sea, and Gulf of Thailand.
\end{abstract}

The cumacean fauna of the West Indian Province (Briggs, 1995) is still quite poorly known, comprising about 35 species from just a few islands (particularly Jamaica, Bermuda, Andros, and Abaco). Most of the species be- long to two families, the Bodotriidae and Nannastacidae, and were collected from very shallow waters or marine caves (e.g., Sars, 1873; Calman, 1907, 1911; Petrescu and Iliffe, 1992; Petrescu et al., 1994; Petrescu,
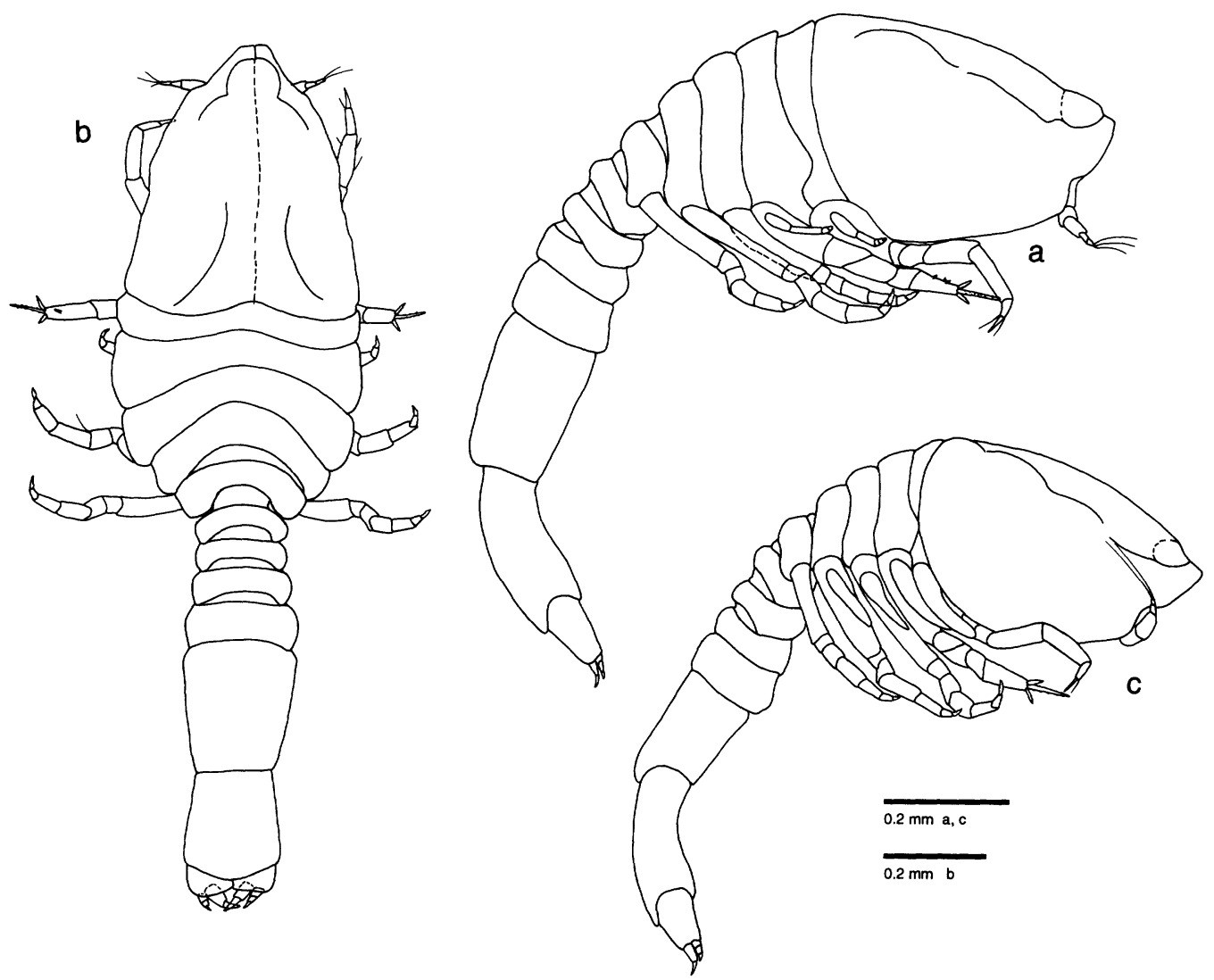

Fig. 1. Humesiana carltoni, new genus, new species; a, adult $\odot$ paratype, lateral view; b, adult $\odot$ paratype, body dorsal view; c, subadult ó paratype, lateral view. 

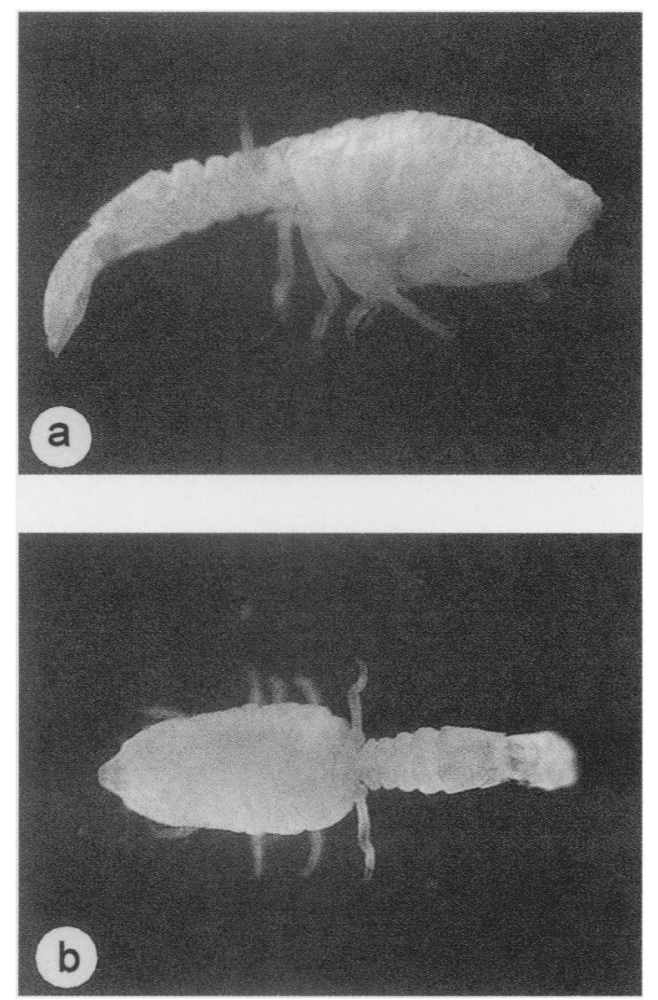

Fig. 2. Humesiana carltoni, new genus, new species; a, adult $\uparrow$ paratype, body side view; b, adult $\odot$ paratype, body dorsal view.

1996, among others). This paper describes a new species assigned to a new genus of the family Nannastacidae which was collected in Guadeloupe and is the first species to be described from the French West Indies.

\section{Family Nannastacidae \\ Humesiana, new genus}

Diagnosis.-Body stout; abdomen as long as cephalothorax; pleonite 6 as long as pleonite 5. Maxilla 1 endites strongly tapered distally. Maxilliped 2 ischium absent. Maxilliped 3 and pereiopods of similar length and shape. Pereiopod 2 ischium absent. Uropods short, robust, peduncles as wide as long.

Type Species.-Humesiana carltoni, new species, by monotypy.

Etymology.-The genus is named for Dr. Arthur Humes, foremost authority on invertebrate-inhabiting copepods and first editor of the Journal of Crustacean Biology, in honor of his contributions to our field and for his appreciation of the smaller things that make up the bulk of the oceanic biodiversity.
Remarks.-This genus, so far represented by the single new species described below, is quite close to some members of the genus Cumella that are also found in the West Indian Province. However, none show the distinct mouthpart appendages, the loss of the ischium on pereiopod 2, and the overall robustness of the pleon and uropods. Several Cumella species possess strongly tapered mandible incisor processes, but in every case the maxillules have normally truncate endites (e.g., Cumella abacoensis Petrescu, 1996). There is a cluster of species, Cumella clavicauda Calman, 1911 (from St. John, U.S. Virgin Islands), $C$. forficula Calman, 1911 (from the Gulf of Thailand), and C. forficuloides Băcescu and Muradian, 1975 (from the Red Sea), all of which have pleonite 6 as long as or longer than pleonite 5 , but all three species have uropods that are only slightly robust (although the endopods are curved inwards), and the ischium is present on pereiopod 2 . Unfortunately, the details of the mouthparts of these species are not known, so further comparisons cannot be made. It may be, however, that Humesiana is a derivative of this group of species.

\section{Humesiana carltoni, new species Figs. 1-5}

Material Examined.-Holotype: USNM 291434, ๆ, collected at the Pointe de la Verdure, Le Gosier, Guadeloupe, French West Indies, $\left(16^{\circ} 14^{\prime} \mathrm{N}, 61^{\circ} 30^{\prime} \mathrm{W}\right), 18$ March 1993, $1.5 \mathrm{~m}$ water depth. Paratypes, USNM $291435,1 \delta, 5$ \&ᄋ, from same locality as holotype.

Description.-Adult $\odot, 2 \mathrm{~mm}$ total length. Carapace about as long as high, lightly sculptured with loose network of shallow depressions; slight dorsolateral ridges run posteriorly from frontal lobe to near posterior margin. Eyelobe as wide as long, with lenses. Pseudorostral lobes short, extending beyond and meeting anterior to eyelobe. Antennal notch deep, anteroventral corner of carapace bluntly rounded.

Antennule peduncle article 1 bent slightly upward, articles 2 and 3 subequal in length, each shorter than article 1. Mandible naviculoid, portion distal to molar strongly narrowed to very small incisor which bears few teeth; molar columnar with crushing surface; seta row with 5 or 6 upwardly directed setae; lacinia present on left mandible only. Maxilla 1 tapering strongly distally to match shape of mandible incisor; endites overlapping anteroposteriorly; one endite bearing 3 strong 

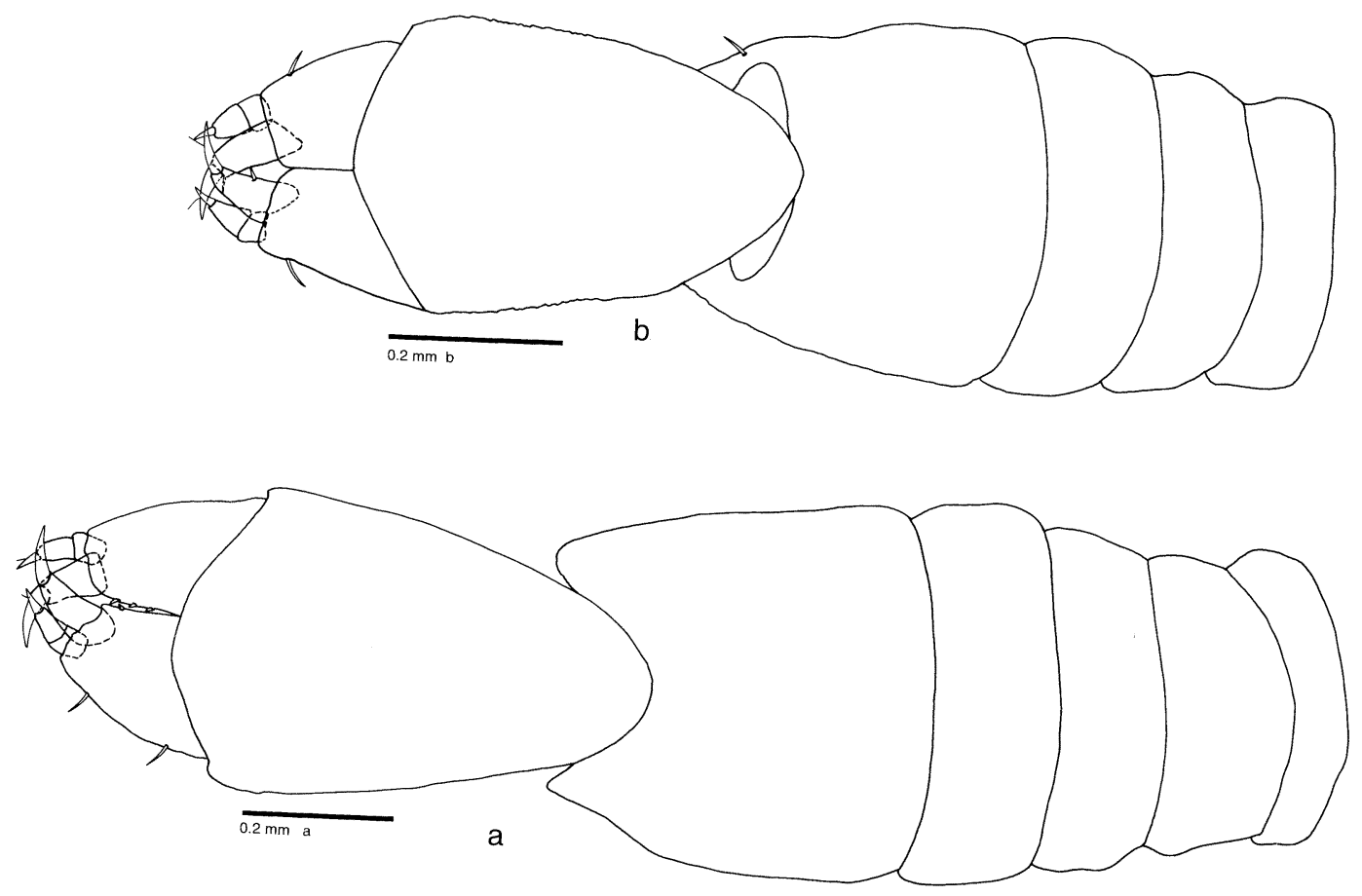

Fig. 3. Humesiana carltoni, new genus, new species; a, adult $\odot$ paratype, pleon, dorsal view; b, subadult $\delta$ paratype, pleon, dorsal view.

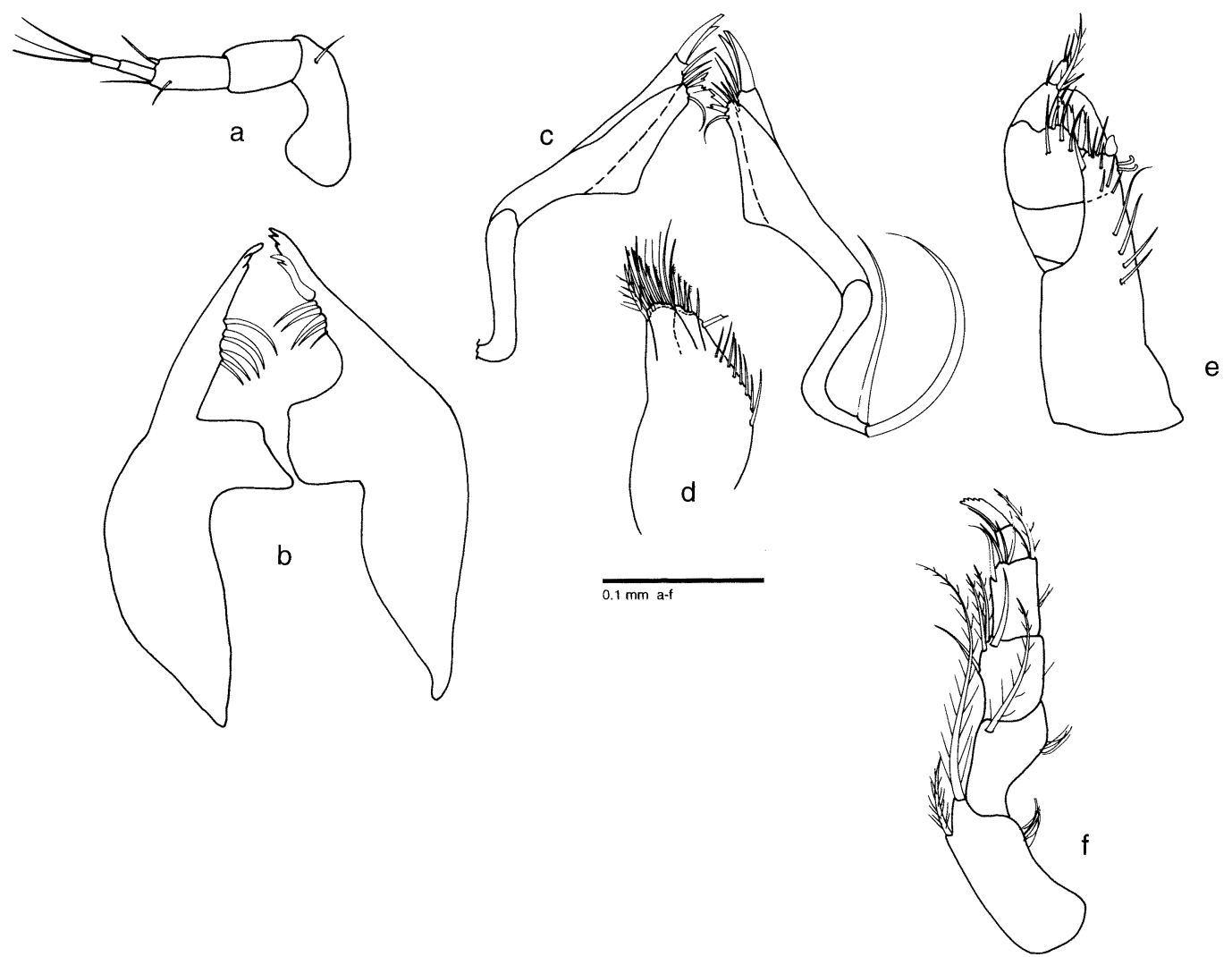

Fig. 4. Humesiana carltoni, new genus, new species, adult $\$$ paratype; a, antennule; b, mandibles, posterior view; c, maxillules; d, maxilla; e, maxilliped 1; f, maxilliped 2 . 


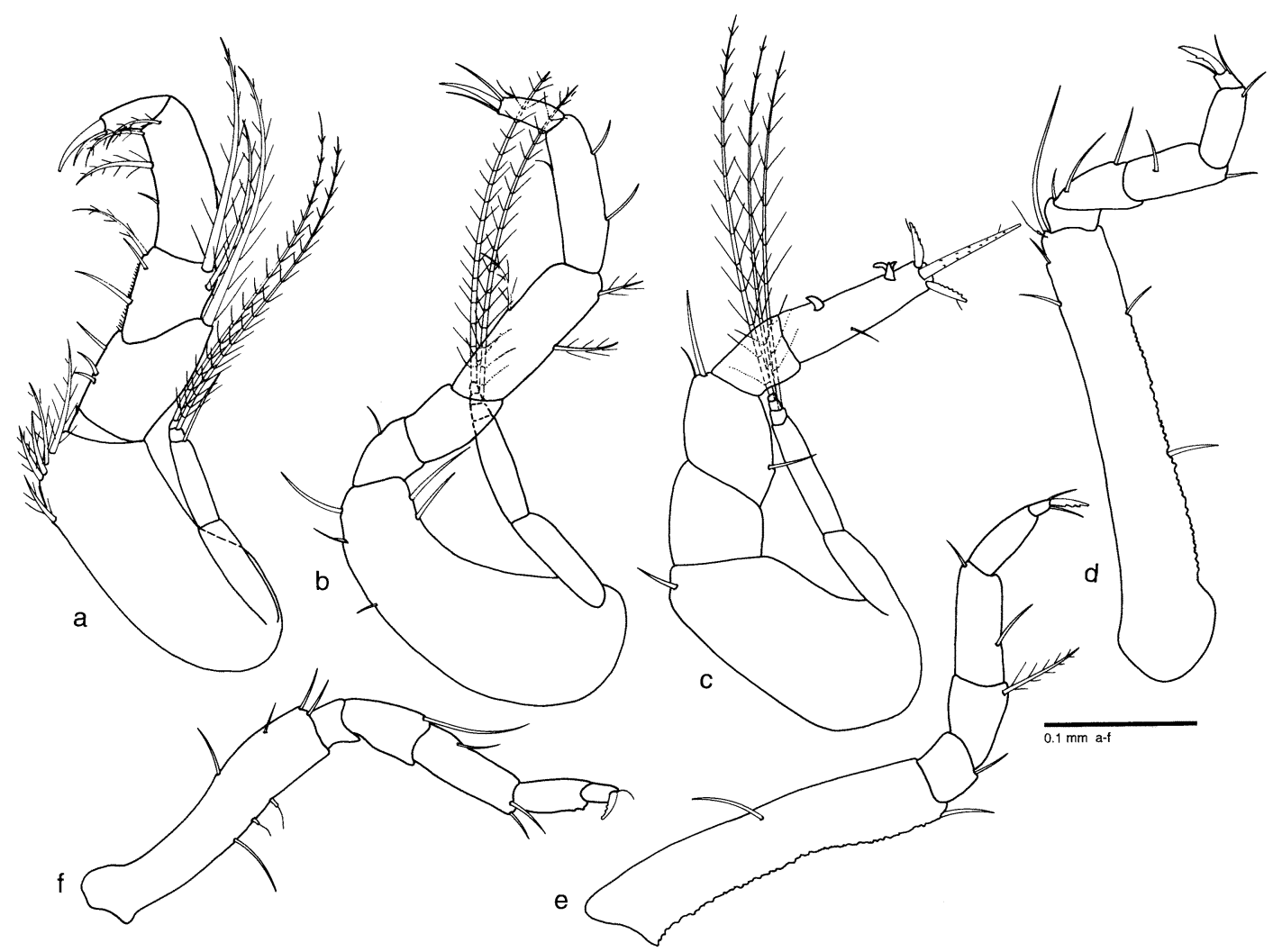

Fig. 5. Humesiana carltoni, new genus, new species, adult $\$$ paratype; a, maxilliped 3; b-f, pereiopods 1-5.

terminal setae and 2 subterminal setae, other with several blunt, microserrate setae distally; palp with 2 setae oriented at right angles to each other. Maxilla 2 with 2 movable endites and 1 fixed endite, all with strong grouping of setae along distal margin.

Maxilliped 1 basis with strong medial endite and entire medial margin curved dorsally; ischium present, small; merus and carpus separate but together forming large spoon-shaped plate with delicate, hyaline medial margin; propodus originates from lateral margin of carpus; dactyl short. Maxilliped 2 basis with single large seta distally on medial margin; ischium absent; merus lateral margin slightly curved outward; carpus and propodus subequal in size and shape; dactyl short, nearly as wide as long, bearing enlarged seta with serrate distal margin. Maxilliped 3 basis shorter than remainder of leg, without any distal or lateral expansions; ischium present, small; merus with very slight distolateral lobe bearing 1 long plumose seta; carpus medial margin with dense covering of minute setae or fringe; propodus curved slightly medially; dactylus bearing long claw-like seta; exopod of 2 articles, terminal article biannulate and bearing only 2 pairs of long plumose setae.

Pereonites similar in length, narrowing posteriorly from pereonite 3 ; pereonite 1 not overlapped by posterior margin of carapace. Pereiopod 1 basis shorter than remainder of leg; carpus and propodus subequal in length; dactylus bears 3 terminal setae; exopod of 2 articles, terminal article triannulate and bearing only 2 pairs of long plumose setae. Pereiopod 2 ischium absent; merus and carpus subequal in length, approximately as wide as long; dactylus elongate, with 2 stout, recurved setae along anterior margin and 3 terminal micro-toothed setae, middle one longest; exopod as in pereiopod 1, with 3 pairs of plumose setae. Pereiopods 3-5 basis as long or longer than remainder of leg, sparsely setose, dactylus with slightly recurved terminal seta.

Pleonite 1 with narrow connection to pereonite 5; pleonites increasing in size posteri- 


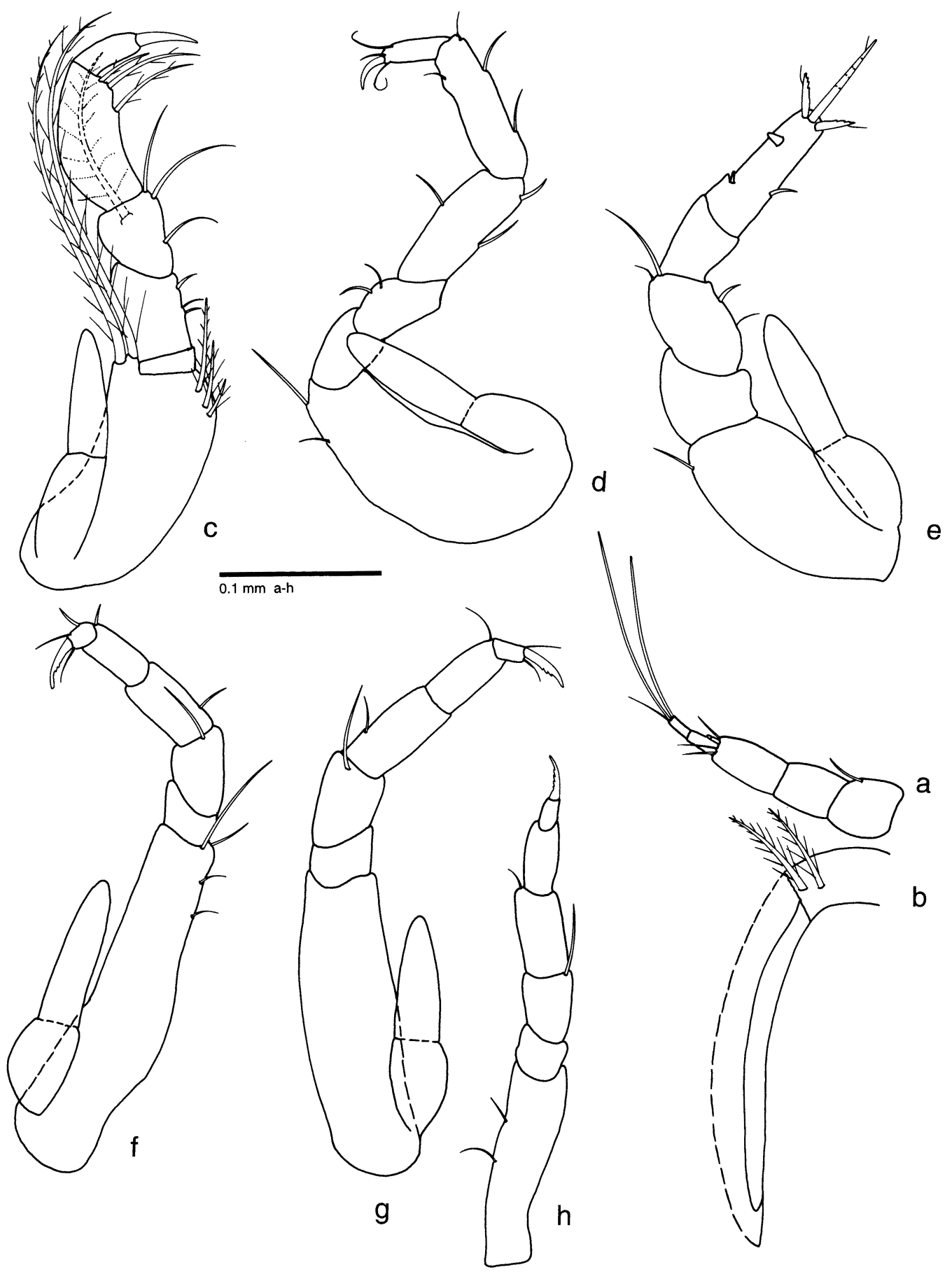

Fig. 6. Humesiana carltoni, new genus, new species, subadult ó paratype; a, antennule; b, antenna; c, maxilliped 3; $\mathrm{d}-\mathrm{h}$, pereiopods $1-5$. 
orly to pleonite 5 which is as long as pleonites 2-4 combined; pleonite 5 posterior margin strongly incised; pleonite 6 as long as pleonite 5 , anterior portion bent slightly ventrally. Uropods very robust; peduncle as wide as long and bearing several small, stout setae along medial margin; rami shorter than peduncle; endopod slightly longer than exopod, with partially fused terminal seta; exopod basal article more than one-third length terminal article; terminal seta articulated.

Subadult $\delta, 2 \mathrm{~mm}$. Similar to subadult o in all respects except the following: carapace antennal notch slightly more broad and shallow; antennule peduncle article 1 equal in length to peduncle article 2; exopods present on maxilliped 3 and pereiopods $1-4$.

Etymology.-This species is named in honor of Dr. James T. Carlton, foremost authority on the distribution and ecology of introduced species, who stood onshore with a flashlight while one of us (LW) collected cumaceans in the dark of night neck-deep in water.

\section{Remarks.-As for genus.}

\section{ACKNOWLEDGEMENTS}

Travel to Guadeloupe was made possible by a grant from the University of Maine Sea Grant office for attendance at a conference on marine biodiversity sponsored by the European organization Diversitas. We are pleased to name this new genus for Arthur Humes, even though it is not a copepod, to honor the high standards of taxonomic publication he set for all of us to meet. I (LW) had a long and fruitful association with Arthur since our earliest meeting regarding the Journal of Crustacean Biology. He was a classical scholar with a broad understanding of crustacean biology, and I'm particularly sad that such a warm and considerate scientist of his stature is not able to be with us to receive the thanks which he so richly deserves.

\section{LITERATURE Cited}

Băcescu, M., and Z. Muradian. 1975. New Cumacea from the Red Sea.-Travaux du Muséum d'Histoire Naturelle "Gigore Antipa" 16: 35-69.

Briggs, J. C. 1995. Global biogeography. Elsevier, Amsterdam. Pp. xvii, 1-452.

Calman, W. T. 1907. On new or rare Crustacea of the Order Cumacea from the collection of the Copenhagen Museum.-Transactions of the Zoological Society of London 18: 1-56.

. 1911. On new or rare Crustacea of the Order Cumacea from the collection of the Copenhagen $\mathrm{Mu}$ seum, Part II.-Transactions of the Zoological Society of London 18: 341-399.

Petrescu, I. 1996. Cumaceans (Crustacea: Cumacea) from Abaco Island (Bahamas). - Travaux du Muséum d'Histoire Naturelle "Gigore Antipa" 36: 157-183.

, and T. M. Iliffe. 1992. Contributions to the knowledge of the cumacean species (Crustacea, Cumacea) of British blue holes (Andros Island, Bahamas Islands). - Travaux du Muséum d'Histoire Naturelle "Gigore Antipa" 32: 283-301.

,$- \longrightarrow$, and S. Sarbu. 1994. Contributions to the knowledge of cumaceans (Crustacea) from Jamaica II, five new species of the Genus Cumella.-Travaux du Muséum d'Histoire Naturelle "Gigore Antipa" 34: 347-367.

Sars, G. O. 1873. Beskrivelse af syv nye Cumaceer fravestindien og det syd-Atlantiske Ocean.-Kongl Svenska Vetenskaps-Akademiens Handlingar 11: 3-30.

RECEIVED: 25 November 1999.

ACCEPTED: 13 January 2000. 